\title{
Imaging in assessing hepatic and peritoneal metastases of gastric cancer: a systematic review
}

\author{
Zhen Wang, Jun-Qiang Chen ${ }^{*}$
}

\begin{abstract}
Background: Hepatic and peritoneal metastases of gastric cancer are operation contraindications. Systematic review to provide an overview of imaging in predicting the status of liver and peritoneum pre-therapeuticly is essential.

Methods: A systematic review of relevant literatures was performed in Pubmed/Medline, Embase, The Cochrane Library and the China Biological Medicine Databases. QUADAS was used for assessing the methodological quality of included studies and the bivariate model was used for this meta-analysis.

Results: Totally 33 studies were included (8 US studies, 5 EUS studies, 22 CT studies, 2 MRI studies and 5 18F-FDG PET studies) and the methodological quality of included studies was moderate. The result of meta-analysis showed that $\mathrm{CT}$ is the most sensitive imaging method [0.74 (95\% Cl: 0.59-0.85)] with a high rate of specificity [0.99 (95\% Cl: 0.97-1.00)] in detecting hepatic metastasis, and EUS is the most sensitive imaging modality [0.34 (95\% Cl: 0.10-0.69)] with a specificity of 0.96 ( $95 \%$ Cl: 0.87-0.99) in detecting peritoneal metastasis. Only two eligible MRI studies were identified and the data were not combined. The two studies found that MRI had both high sensitivity and specificity in detecting liver metastasis.
\end{abstract}

Conclusion: US, EUS, CT and ${ }^{18}$ F-FDG PET did not obtain consistently high sensitivity and specificity in assessing liver and peritoneal metastases of gastric cancer. The value of laparoscopy, PET/CT, DW-MRI, and new PET tracers such as ${ }^{18} \mathrm{~F}$-FLT needs to be studied in future.

\section{Background}

Although the decreasing incidence and mortality, gastric cancer remains the fourth common cancer and the second leading cause of cancer-related deaths with poor prognosis worldwide $[1,2]$. As we known, treatment option, decision-making and prognosis of gastric cancer are strongly dependent on the extent of tumor (tumor extension, nodal involvement and distant metastases), accurately pretherapeutic staging is essential [3].

It was reported that the rate of liver metastasis in gastric cancer can achieve 5-9\% $[4,5]$, and the number of liver metastasis is a significant prognostic factor of gastric cancer $[4,6]$. Generally speaking, gastric cancer has extrahepatic metastasis if hepatic metastasis, such as lymph node involvement and peritoneal seeding. Surgical resection is rarely required under these circumstances [5]. Peritoneal metastasis, mainly induced by the dissemination of

\footnotetext{
* Correspondence: gxmufh@163.com

* Correspondence: gxmufh@163.com Guangxi Medical University, 6 Shuang Yong Road, Nanning 530021, Guangxi, PR China
}

(c) 2011 Wang and Chen; licensee BioMed Central Ltd. This is an Open Access article distributed under the terms of the Creative Commons Attribution License (http://creativecommons.org/licenses/by/2.0), which permits unrestricted use, distribution, and reproduction in any medium, provided the original work is properly cited.

free tumor cells from the primary gastric cancer, is one of the most common types of spread and the causes of death [7]. Peritoneal metastasis of gastric cancer was considered to be operation contraindication and the most difficult type for treatment [8].

Studies suggested that imaging methods of evaluating the pre-operative status of hepatic and peritoneal metastases have two effects [9,10]: 1) avoiding unnecessary laparotomy; 2) assessing the effectiveness of neoadjuvant protocols in the absence of histopathological confirmation. Although systematic review and meta-analysis of imaging in assessing local staging and lymph node status of gastric cancer were performed [11,12], there is no consensus on the most sensitive imaging method for detecting hepatic and peritoneal metastases of gastric cancer now. Theoretically pre-operative staging of gastric cancer should mainly focus on assessing distant metastases but not local staging or lymph node status, since if one patient has distant metastases, an exploratory laparotomy always can be avoided [13]. 
The objective of this systematic review is to provide a comprehensive and up-to-date overview of sensitivity and specificity of imaging [ultrasonography(US), Endoscopic ultrasound(EUS), computed tomography (CT), magnetic resonance imaging(MRI), and ${ }^{18} \mathrm{~F}$-fluorodeoxyglucose positron emission tomography $\left({ }^{18} \mathrm{~F}-\mathrm{FDG}\right.$ PET) in detecting hepatic and peritoneal metastases of gastric cancer.

\section{Methods}

\section{Search strategy}

A computer-aided search of the Pubmed/Medline, Embase, The Cochrane Library (issue 1, 2011), and the China Biological Medicine Database (CBM) was conducted to identify relevant publications on the diagnostic performance of imaging (US, EUS, CT, MRI, and ${ }^{18}$ F-FDG PET) in detecting hepatic and peritoneal metastases of gastric cancer. The upper limit of search date was not limited, and the lower limit was February, 2011. The following search phrases were used: stomach neoplasms, stomach cancer, stomach carcinoma, stomach tumor, gastric cancer, gastric carcinoma, gastric neoplasms, gastric tumor, liver metastasis/metastases, hepatic metastasis/metastases, peritoneal metastasis/ metastases, peritoneal seeding, peritoneal involvement, peritoneal carcinomatosis, sensitivity, specificity, accuracy. Both free text and $\mathrm{MeSH}$ search for keywords were employed. The language was not limited. To search more potentially relevant trials, reference lists from included studies of electronic searching were screened.

\section{Inclusion and exclusion criteria}

Inclusion criteria for this meta-analysis

1. Studies assessed the diagnostic value of imaging (US, EUS, CT, MRI, or ${ }^{18}$ F-FDG PET) in detecting hepatic or peritoneal metastasis of gastric cancer.

2. The standard of reference had to be a surgery or histopathological examination.

3. True-positive, false-positive, true-negative, and false-negative results of imaging methods could be calculated for per-patient.

4. PET had to be performed with intravenous administration of ${ }^{18}$ F-FDG.

\section{Exclusion criteria for this meta-analysis}

1. Studies included patients with non-adenocarcinoma (eg, lymphoma).

2. Studies only assessed gastric cancer confined to a specific part of the stomach (eg, cardia or gastroesophageal junction), which could not represent overall place where tumour may occur.
3. Studies included patients who received radiotherapy or chemotherapy pre-operatively, which may cause downstaging. (Because neoadjuvant protocols can lead to tumor downstaging and affect the diagnostic accuracy of imaging)

4. Vitro studies and studies performed in animals.

5. Studies with a sample size less than 10 .

6. Studies were not original research (eg, systematic review)

Study selection was performed by two authors (Z. Wang and J.Q.Chen) independently according to the inclusion and exclusion criteria. When we found eligible studies with published data more than once, we only included the article with the most patients. Disagreements were resolved by consensus.

\section{Data extraction and quality assessment}

Two authors (Z. Wang and J.Q.Chen) extracted data using pre-defined tables, which included items as follows: author and publication time, country of source, sample size, interpreters, standard reference, image modality (US, EUS, CT, MRI, or ${ }^{18}$ F-FDG PET), imaging technique (transducer frequency for US and EUS; use of intravenous contrast, section thickness and gap for CT; use of intravenous contrast, section thickness, gap, field strength and coil type for MRI; time of fasting before scanning, FDG dose, time interval between FDG administration and scanning, attenuation correction, and reconstruction method for ${ }^{18} \mathrm{~F}$-FDG $\mathrm{PET}$ ) and test result (true positive, false positive, true negative and false negative on per patient basis).

Fourteen items of QUADAS were used to assess the methodological quality of eligible studies [14]. Descriptions of each item: Yes (score 2); Unclear (score 1); No (score 0 ). Total quality score was the summary score of each item. We consider that studies with a total score more than 17 were regarded as high methodological quality, and less than 17 as low methodological quality.

\section{Data analysis}

Pooled estimates of sensitivity, specificity and diagnostic odds ratio (DOR) of imaging (with corresponding 95\% confidence intervals [CIs]) were analyzed based on the bivariate model [15]. The bivariate model uses a random effect approach for both sensitivity and specificity, which allows for heterogeneity beyond chance as a result of clinical and methodological differences between studies, and the bivariate model is considered as a more valid statistical model for diagnostic meta-analysis $[16,17]$. To graphically present the results, we plotted the hierarchical summary receiver operating characteristic (HSROC) curves [16]. As a potential cause of heterogeneity in sensitivity and specificity among the included 
studies, threshold/cut off effect was tested with the Spearman correlation coefficient between the logit of sensitivity and logit of 1-specificity; heterogeneity induced by factors other than threshold/cut off effect was assessed by using the Cochran Q statistic ( $\chi^{2}$ test). Statistical significance of heterogeneity test was assumed when a $P$ value was less than 0.10 . As a concern for meta-analysis of diagnostic trials, publication bias was tested using the funnel plot and Deeks test [18], which was conducted by a regression of diagnostic log odds ratio against $1 /$ sqrt(effective sample size), weighting by effective sample size, with $P<0.10$ for the slope coefficient indicating significant asymmetry. Meta-Disc (version 1.4), Stata (version 11.0), especially the midas and metandi commands were used for statistical analysis $[19,20]$ (Appendix).

\section{Results}

\section{Study selection and description}

According to the pre-defined search strategy, total 1310 literatures were revealed: 449 from Pubmed/Medline, 853 from Embase, 0 from the Cochrane Library and 8 from CBM. By screening the tittles and abstracts we found that lots of articles were irrelevant and some were identified in more than one database, thus 101 studies remained for potential inclusion and were obtained in full-text version. After reviewing the full text, 68 studies were excluded. The mainly reasons for excluded studies were as follows: non-original research(eg. review articles), not reporting the diagnostic performance of liver or peritoneal metastasis, insufficient data to construct a $2 \times 2$ contingency table, inclusion of patients with nonadenocarcinoma, gastric carcinoma confined to a specific part of the stomach or included patients received neoadjuvant chemotherapy. At last 33 studies [21-53] were included (8 US studies, 5 EUS studies, 22 CT studies, 2 MRI studies and $5{ }^{18} \mathrm{~F}$-FDG PET studies). The process of study selection was listed in Figure 1.

The 8 US studies were published between 1983 and 2004, and the sample size varied from 21 to 125 (Table 1). The 5 EUS studies were published between 1990 and 2005, and the sample size ranged from 48 to 402 (Table 2). The 22 CT studies were published between 1994 and 2010, and the sample size varied from 36 to 640 (Table 3). The 2 MRI studies were published between 2006 and 2007, and the sample size varied from 25 to 35 (Table 4). The $5{ }^{18}$ F-FDG PET studies were published between 1998 and 2006, and the sample size varied from 23 to 124 . Among the $5{ }^{18}$ F-FDG PET studies, one study [35] used two kinds of scanners (PT931/04 scanner and SET2400W scanner), and we analyzed the data separatedly according to the kind of scanner (Table 5).

The quality of included studies was assessed based on the 14 items of QUADAS (Table 6). The total score varied from 14 to 22 in US studies, 17 to 25 in EUS studies, 14 to 23 in CT studies, 15 to 19 in MRI studies, and 16 to 21 in ${ }^{18}$ F-FDG PET studies.

\section{Results of meta-analysis \\ Heterogeneity tests}

Table 7 presented the Spearman correlation coefficient for each test. The $p$ value was larger than 0.1 except for EUS in the detection of peritoneal metastasis.

Table 8 presented the results of Cochrane-Q test. For EUS in the detection of peritoneal metastasis, Cochrane-Q test failed to be conducted using the metandi command in stata software due to unstability. Except for US and PET in the detection of peritoneal metastasis, the $p$ value of Cochrane-Q test was less than 0.1 , which suggested significant heterogeneity between included studies.

\section{Diagnostic value \\ Liver metastasis}

The data were available in 8 US studies [21-27,29], 2 EUS studies [27,31], 18 CT studies [21-23,27,29,36,39, 41,43-51,53], 2 MRI studies [37,38], and $4{ }^{18}$ F-FDG PET studies $[35,36,41,42]$. Meta-analysis was based on the bivariate model in the presence of significant heterogeneity.

Pooled sensitivity for US, CT and ${ }^{18}$ F-FDG PET in detecting liver metastasis were 0.54 (95\% CI: 0.34-0.73), 0.74 (95\% CI: $0.59-0.85)$ and 0.70 (95\% CI: 0.36-0.90) respectively (Table 9).

Pooled specificity for US, CT and ${ }^{18}$ F-FDG PET in detecting liver metastasis were 0.98 (95\% CI: 0.90-0.99), 0.99 (95\% CI: 0.97-1.00) and 0.96 (95\% CI: 0.81-0.99), respectively. (Table 9)

Pooled DOR for US, CT and 18F-FDG PET in detecting liver metastasis were 50.25 (95\% CI: 13.48-187.32), 251.14 (95\% CI: 83.53-755.07) and 56.46 (95\% CI: 8.47376.23) respectively (Table 9 ).

Only two studies' data were sufficient for EUS and MRI, and we did not conduct pooled analysis, but presented the result of each study in Table 10.

\section{Peritoneal metastasis}

The data were available in 5 US studies [21-23,25,29], 4 EUS studies [30-33], 15 CT studies [21,22,29,34, $36,39,40,43-48,52,53]$ and $4{ }^{18}$ F-FDG PET studies [34-36,42]. Meta-analysis was based on the bivariate model in the presence of significant heterogeneity.

Pooled sensitivity for US, EUS, CT and ${ }^{18}$ F-FDG PET in detecting peritoneal metastasis were 0.09 (95\% CI: 0.03-0.21), 0.34 (95\% CI: 0.10-0.69), 0.33 (95\% CI: 0.16$0.56)$ and 0.28 (95\% CI: 0.17-0.44) respectively (Table 9).

Pooled specificity for US, EUS, CT and ${ }^{18}$ F-FDG PET in detecting peritoneal metastasis were 0.99 (95\% CI: 0.96-1.00), 0.96 (95\% CI: 0.87-0.99), 0.99 (95\% CI: $0.98-1.00)$ and 0.97 (95\% CI: 0.83-1.00), respectively (Table 9). 


\section{Computer-aided search revealed studies $\mathrm{N}=1310$}

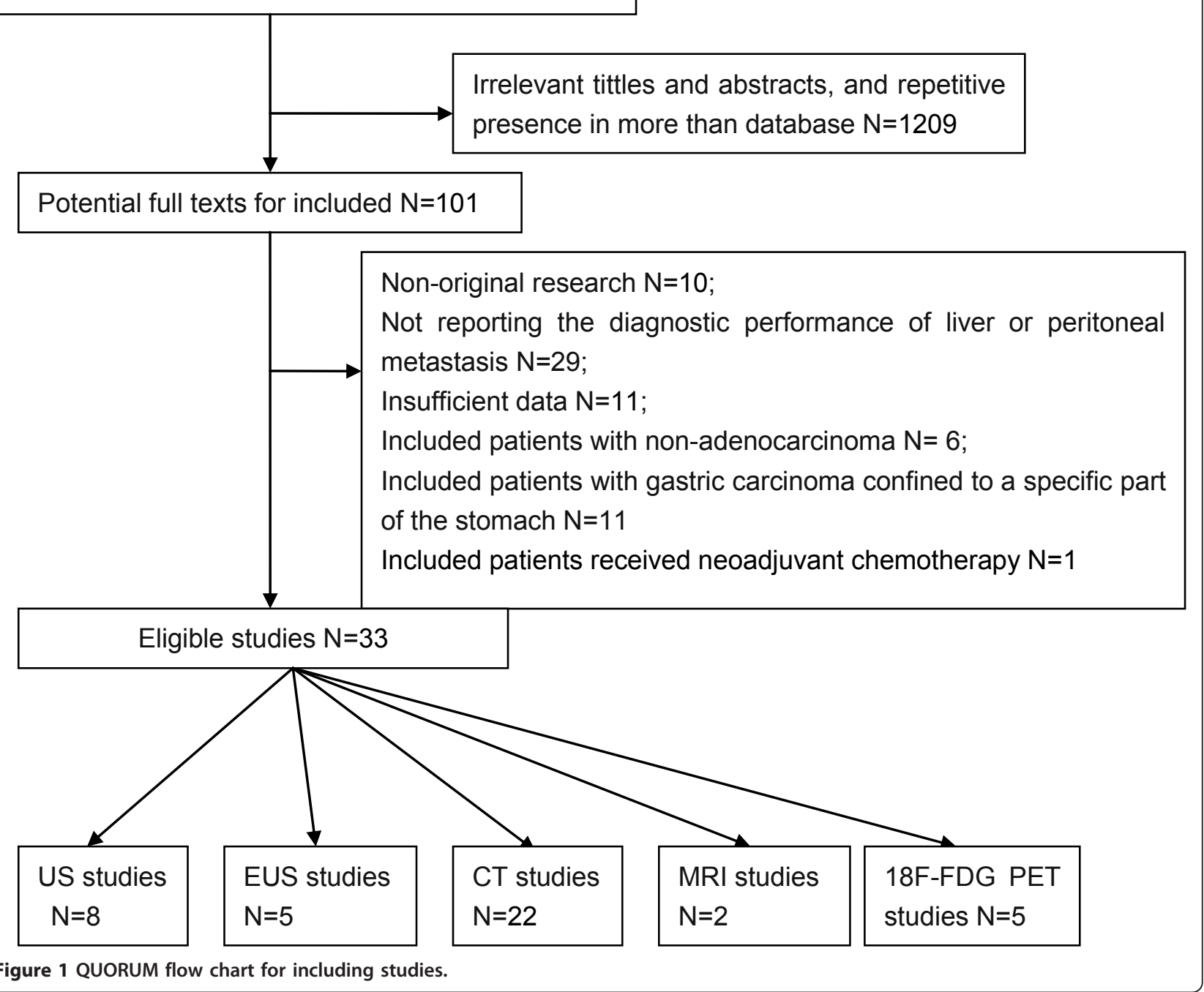

Table 1 Characteristics of the eight included US studies

\begin{tabular}{|c|c|c|c|c|c|}
\hline $\begin{array}{c}\text { Study } \\
\text { (year, reference) }\end{array}$ & County & $\begin{array}{l}\text { No. of } \\
\text { patients }\end{array}$ & $\begin{array}{l}\text { Transducer } \\
\text { frequency } \\
(\mathrm{MHz})\end{array}$ & Interpreter(s) & Reference standard \\
\hline Kim $1997[21]$ & $\begin{array}{l}\text { South } \\
\text { Korea }\end{array}$ & 95 & 3.5 or 5 & Two radiologists independently & Surgical and pathological findings \\
\hline Stell 1996 [22] & $\begin{array}{l}\text { United } \\
\text { Kingdom }\end{array}$ & 103 & 3.5 & Experienced personnel & Histological examination \\
\hline Asencio 1997 [23] & Germany & 71 & NCD & NCD & $\begin{array}{c}\text { Surgical and histologic } \\
\text { evaluation }\end{array}$ \\
\hline Possik 1986 [24] & $\begin{array}{l}\text { United } \\
\text { States }\end{array}$ & 82 & NCD & NCD & Surgical and histologic evaluation \\
\hline Derchi 1983 [25] & $\begin{array}{l}\text { United } \\
\text { States }\end{array}$ & 21 & 3.5 & Two authors of the study & Surgical and pathological examization. \\
\hline Liao 2004 [26] & China & 125 & 3.5 or 6.0 & NCD & Operative and pathological examination \\
\hline Ozmen 2003 [27] & $\begin{array}{l}\text { United } \\
\text { States }\end{array}$ & 48 & NCD & NCD & Histological examination \\
\hline Kayaalp 2002 [28] & $\begin{array}{l}\text { United } \\
\text { Kingdom }\end{array}$ & 118 & NCD & A consultant radiologist & Histopathological examinations \\
\hline
\end{tabular}


Table 2 Characteristics of the five included EUC studies

\begin{tabular}{cccccc}
\hline $\begin{array}{c}\text { Study } \\
\text { (year, reference) }\end{array}$ & County & $\begin{array}{c}\text { No. of } \\
\text { patients }\end{array}$ & $\begin{array}{c}\text { Transducer } \\
\text { frequency } \\
\text { (MHz) }\end{array}$ & Interpreter(s) & Reference standard \\
\hline Ozmen 2003 [27] & $\begin{array}{c}\text { United } \\
\text { States } \\
\text { Chu 2004 [30] }\end{array}$ & 48 & NCD & NCD & Histological examination \\
Tio 1990 [31] & $\begin{array}{l}\text { States } \\
\text { United }\end{array}$ & 84 & 7.5 or 12 & $\begin{array}{c}\text { An author } \\
\text { of the study } \\
\text { NCD }\end{array}$ & Surgical and pathologic examination \\
Chen 2002 [32] & $\begin{array}{l}\text { United } \\
\text { States }\end{array}$ & 65 & 7.5 or 12 & $\begin{array}{c}\text { An author } \\
\text { of the study } \\
\text { Experienced } \\
\text { radiologists }\end{array}$ & Surgical and pathological findings \\
Lee 2005 [33] & United & 301 & 7.5 or 12 & Surgery, histopathology or cytology \\
\hline
\end{tabular}

NCD: not clearly described.

Pooled DOR for US, EUS, CT and ${ }^{18}$ F-FDG PET in detecting peritoneal metastasis were 10.63 (95\% CI: 1.54-73.36), 13.07 (95\% CI: 6.42-26.62), 66.18 (95\% CI: 27.28-160.53) and 12.49 (95\% CI: 2.22-70.10), respectively (Table 9).

\section{HSROC curves}

We plotted HSROC curves to graphically present the results (Figure 2, 3, 4, 5, 6, 7, 8). In HSROC curves, the index test's sensitivity (true positive rate) was plotted on the $y$ axis against 1-specificity (false negative rate) on the $\mathrm{x}$ axis. In addition, the $95 \%$ confidence region and a 95\% prediction region around the pooled estimates were plotted to illustrate the precision with which the pooled values were estimated (confidence ellipse of a mean) and to show the amount of between study variation (prediction ellipse; the likely range of values for a new study) [16].

\section{Publication bias}

Because the number of included studies was few, we only explored publication bias using the data of CT in detecting liver metastasis, which included 18 studies. As a result, the funnel plot seemed symmetrical with a $P$ value of 0.66 , and this suggested a low risk of publication bias (Figure 9).

\section{Discussion}

As far as we know, this systematic review is the first study that evaluates the summary estimates of sensitivity and specificity of five imaging modalities which are currently used for the detection of hepatic and peritoneal metastases. The pooled result basing on the bivariate model showed that $\mathrm{CT}$ is the most sensitive imaging method [0.74 (95\% CI: 0.59-0.85)] with a high rate of specificity [0.99 (95\% CI: 0.97-1.00)] in detecting hepatic metastasis, and EUS is the most sensitive imaging modality [0.34 (95\% CI: 0.10-0.69)] with a specificity of 0.96 (95\% CI: 0.87-0.99) in detecting peritoneal metastasis.

The strengths of this systematic review were its welldefined search strategy, selection of study according to the strict inclusion criteria, independent methodological quality assessment by two reviewers and more valid statistical model for diagnostic meta-analysis in the presence of heterogeneity. Of course, our study was not faultless. Firstly, some included studies had a low methodological quality. For instance, the two eligible MRI studies only included patients with advanced gastric cancer, this might lead to bias by non-representative patient spectrum. Additionally, the great mass of included studies had a potential bias of partial verification, which was interpreted as not all of the study group receive confirmation of the diagnosis by the reference standard. It was especially noted that all included studies did not report the uninterpretable/intermediate test results, which might lead to the biased assessment of the test characteristics. Secondly, except for CT studies, the number of eligible studies is less. Besides many clinical characteristics of patients (such as Lauren classification) and technology parameters of imaging (such as slice Thickness and interslice gap of CT) were mixed or missing in included studies, so we failed to perform subgroup analysis or meta-regression, which might find out other possible causes of heterogeneity. Thirdly, due to few eligible studies, we only used the data of CT in detecting liver metastasis to test publication bias, therefore potential bias might occur. Fourthly, heterogeneity caused by threshold/cut off effect was present for EUS in detecting peritoneal metastasis, thus we should interpreted the pooled results prudently.

DOR, which means the ratio of the odds of positive test results in diseased group relative to the odds of positive test results in non-diseased group, is considered as another important indicator of test accuracy that combines the data from sensitivity and specificity into a new index [54]. The value of a DOR ranges from zero to infinity, with higher value indicating higher accuracy. A DOR of 1.0 shows that a test can not distinguish between patients with the disease and those without it. We found that CT seemed to be more helpful in the 
Table 3 Characteristics of the twenty-two included CT studies

\begin{tabular}{|c|c|c|c|c|c|c|}
\hline $\begin{array}{c}\text { Study } \\
\text { (year, } \\
\text { reference) }\end{array}$ & County & $\begin{array}{l}\text { No. of } \\
\text { patients }\end{array}$ & $\begin{array}{c}\text { Use of } \\
\text { intravenous } \\
\text { contrast } \\
\text { (dose) }\end{array}$ & $\begin{array}{c}\text { Section } \\
\text { thickness } \\
(\mathrm{mm}), \text { gap } \\
(\mathrm{mm})\end{array}$ & Interpreter(s) & Reference standard \\
\hline$\underset{1997[21]}{\text { Kim }}$ & $\begin{array}{l}\text { South } \\
\text { Korea }\end{array}$ & 95 & NCD & 10,10 & $\begin{array}{l}\text { Two radiologists } \\
\text { independently }\end{array}$ & $\begin{array}{l}\text { Surgical and pathological } \\
\text { findings }\end{array}$ \\
\hline $\begin{array}{c}\text { Stell } \\
1996[22]\end{array}$ & $\begin{array}{l}\text { United } \\
\text { Kingdom }\end{array}$ & 103 & NCD & NCD & Experienced personnel & Histological examination \\
\hline $\begin{array}{l}\text { Asencio } \\
1997[23]\end{array}$ & Germany & 71 & NCD & NCD & NCD & $\begin{array}{c}\text { Surgical and histologic } \\
\text { evaluation }\end{array}$ \\
\hline $\begin{array}{l}\text { Ozmen } \\
2003[27]\end{array}$ & $\begin{array}{l}\text { United } \\
\text { States }\end{array}$ & 48 & NCD & NCD & NCD & Histological examination \\
\hline $\begin{array}{c}\text { Nozoe } \\
1999[28]\end{array}$ & $\begin{array}{l}\text { United } \\
\text { States }\end{array}$ & 36 & NCD & NCD & $\begin{array}{l}\text { An experienced } \\
\text { gynecologist }\end{array}$ & Operation findings \\
\hline $\begin{array}{l}\text { Kayaalp } \\
2002[29]\end{array}$ & $\begin{array}{l}\text { United } \\
\text { Kingdom }\end{array}$ & 118 & NCD & 10,10 & A consultant radiologist & Histopathological examinations \\
\hline $\operatorname{Lim}_{2006[34]}$ & $\begin{array}{l}\text { South } \\
\text { Korea }\end{array}$ & 124 & $\begin{array}{l}60 \% \text { iodinated contrast } \\
\text { material }(2 \mathrm{~mL} / \mathrm{kg})\end{array}$ & $\begin{array}{l}1.0-1.5 \text { or } 3.0- \\
7.0, \mathrm{NCD}\end{array}$ & $\begin{array}{c}\text { Three experienced } \\
\text { gastrointestinal } \\
\text { radiologists }\end{array}$ & $\begin{array}{l}\text { Surgical and histopathologic } \\
\text { standards }\end{array}$ \\
\hline $\begin{array}{c}\text { Chen } \\
2005[36]\end{array}$ & $\begin{array}{l}\text { United } \\
\text { States }\end{array}$ & 68 & $\begin{array}{l}\text { 60\% iodine } \\
\text { (maximum } 150 \mathrm{~mL} \text { ) }\end{array}$ & 7, NCD & An abdominal radiologist & $\begin{array}{l}\text { Surgical and histological } \\
\text { classification }\end{array}$ \\
\hline $\begin{array}{l}\text { Chamadol } \\
2008[39]\end{array}$ & Thailand & 64 & $\begin{array}{l}\text { lodinated contrast material } \\
\qquad(100 \mathrm{~mL})\end{array}$ & $8, N C D$ & $\begin{array}{l}\text { An experienced } \\
\text { radiologist }\end{array}$ & Surgical-pathologic results \\
\hline $\begin{array}{c}\text { Yajima } \\
2006[40]\end{array}$ & $\begin{array}{l}\text { United } \\
\text { States }\end{array}$ & 413 & $\begin{array}{l}\text { lodinated contrast material } \\
\text { (NCD) }\end{array}$ & $10, N C D$ & Expert radiologists & $\begin{array}{l}\text { Clinical, surgical reports, } \\
\text { histopathologic findings }\end{array}$ \\
\hline $\begin{array}{c}\text { Yun } \\
2005[41]\end{array}$ & $\begin{array}{l}\text { United } \\
\text { States }\end{array}$ & 81 & $\begin{array}{c}\mathrm{NCD} \\
(2 \mathrm{~mL} / \mathrm{kg})\end{array}$ & $3-5, N C D$ & NCD & Histopathologic examination \\
\hline$\underset{2005[43]}{\operatorname{Kim}}$ & $\begin{array}{l}\text { United } \\
\text { States }\end{array}$ & 124 & lopromide (150 ml) & 5.0, NCD & $\begin{array}{l}\text { Two experienced } \\
\text { gastrointestinal radiologists }\end{array}$ & Histopathologic analysis \\
\hline $\begin{array}{c}\text { D'Elia } \\
2000[44]\end{array}$ & Germany & 127 & $\begin{array}{l}\text { Non-ionic contrast medium } \\
\qquad(200 \mathrm{ml})\end{array}$ & 10,10 & Two radiologists & Histopathologic staging \\
\hline $\begin{array}{l}\text { Adachi } \\
1997[45]\end{array}$ & $\begin{array}{l}\text { United } \\
\text { States }\end{array}$ & 56 & $\begin{array}{l}\text { Loparimon or omnipaque } \\
\qquad(100 \mathrm{ml})\end{array}$ & $N C D, N C D$ & One radiologist & $\begin{array}{c}\text { Surgical and histological } \\
\text { diagnosis }\end{array}$ \\
\hline $\begin{array}{l}\text { Shinohara } \\
2005[46]\end{array}$ & Japan & 112 & $\begin{array}{l}\text { Non-ionic contrast medium } \\
\qquad(100 \mathrm{ml})\end{array}$ & $2.5,2.5$ & Two authors of the study & $\begin{array}{c}\text { Surgical and histological } \\
\text { diagnosis }\end{array}$ \\
\hline $\begin{array}{c}\text { Davies } \\
1997[47]\end{array}$ & $\begin{array}{l}\text { United } \\
\text { Kingdom }\end{array}$ & 105 & $\begin{array}{l}\text { Ultravist } \\
(150 \mathrm{ml})\end{array}$ & 10,5 & One radiologist & TNM histopathological stage \\
\hline $\begin{array}{c}\text { Yan } \\
2007[48]\end{array}$ & China & 220 & $\begin{array}{l}\text { Non-ionic contrast medium } \\
\qquad(1.5 \mathrm{ml} / \mathrm{kg})\end{array}$ & 3.75-5, NCD & Two radiologists & $\begin{array}{c}\text { Surgical and histological } \\
\text { diagnosis }\end{array}$ \\
\hline $\begin{array}{c}\text { Roic } \\
1994[49]\end{array}$ & Slovenia & 45 & loxitalamate (100 ml) & $8, N C D$ & NCD & $\begin{array}{l}\text { Surgical and pathological } \\
\text { finding }\end{array}$ \\
\hline $\begin{array}{l}\text { Gamón } \\
2002[50]\end{array}$ & Spain & 50 & $\begin{array}{l}\text { non-ionic iodated contrast } \\
\text { medium }(120 \mathrm{ml})\end{array}$ & 5,4 & $\begin{array}{l}\text { A single experienced } \\
\text { radiologist }\end{array}$ & $\begin{array}{c}\text { Surgical and pathological } \\
\text { diagnosis }\end{array}$ \\
\hline $\begin{array}{l}\text { Zhang } \\
2002[51]\end{array}$ & China & 43 & Cardiografin (80-100 ml) & $5-10,5-10$ & Two radiologists & $\begin{array}{c}\text { Surgical and pathological } \\
\text { examination }\end{array}$ \\
\hline $\begin{array}{c}\text { Yan } \\
2010[52]\end{array}$ & China & 640 & $\begin{array}{l}\text { lopromide } \\
\text { (180 ml) }\end{array}$ & $5,2.5$ & Two radiologists & $\begin{array}{l}\text { Surgical and pathological } \\
\text { findings }\end{array}$ \\
\hline $\begin{array}{c}\text { Pan } \\
2010[53]\end{array}$ & China & 350 & $\begin{array}{l}\text { lopromide } \\
(180 \mathrm{ml})\end{array}$ & $5, N R$ & Two experienced physicians & $\begin{array}{l}\text { Surgical and pathological } \\
\text { findings }\end{array}$ \\
\hline
\end{tabular}

NCD: not clearly described.

detection of liver and peritoneal metastases with a pooled DOR 251.14 (95\% CI: 83.53-755.07) and 66.18 (95\% CI: 27.28-160.53) respectively. Unlike traditional SROC plots, HSROC curves was plotted based on hierarchical models in our meta-analysis, which clearly presented the result of a global summary of test performance, the $95 \%$ confidence ellipse around the mean values of sensitivity and specificity of radiographer reporting, as well as a $95 \%$ prediction ellipse for individual value of sensitivity and specificity.

Previous studies reported that sensitivity of US ranged from $0.36-0.87$ in detecting liver metastasis $[22,25,27]$ and 0.05-0.33 in detecting peritoneal metastasis [25,29]. Then most of these studies excluded patients with obvious distant metastases, which might be the reason of low sensitivity of US in detecting liver and peritoneal 
Table 4 Characteristics of the two included MRI studies

\begin{tabular}{|c|c|c|c|c|c|c|c|}
\hline Study & County & $\begin{array}{l}\text { No. of } \\
\text { patients }\end{array}$ & $\begin{array}{l}\text { Use of } \\
\text { intravenous } \\
\text { contrast } \\
\text { (dose) }\end{array}$ & $\begin{array}{c}\text { Section } \\
\text { thickness } \\
(\mathrm{mm}), \\
\text { gap } \\
(\mathrm{mm})\end{array}$ & $\begin{array}{l}\text { Field } \\
\text { strength } \\
\text { (T), coil } \\
\text { type }\end{array}$ & Interpreter(s) & $\begin{array}{l}\text { Reference } \\
\text { Standard }\end{array}$ \\
\hline $\begin{array}{l}\text { Tang } \\
2006 \\
{[37]}\end{array}$ & China & 25 & $\begin{array}{l}\text { Gadolinium, } 0.1 \mathrm{mmol} / \\
\mathrm{kg}\end{array}$ & $10, N C D$ & $\begin{array}{l}0.5 \text {, array body } \\
\text { coil }\end{array}$ & $\begin{array}{l}\text { Two experienced MRI } \\
\text { specialists }\end{array}$ & $\begin{array}{c}\text { Surgical and } \\
\text { histopathologic } \\
\text { examination }\end{array}$ \\
\hline $\begin{array}{c}\mathrm{Li} \\
2007 \\
{[38]}\end{array}$ & China & 35 & $\begin{array}{c}\text { Gadolinium, } 0.1 \mathrm{mmol} / \\
\mathrm{kg}\end{array}$ & $\begin{array}{l}\text { NCD, } \\
\text { NCD }\end{array}$ & $\begin{array}{c}1.5, \text { Phased } \\
\text { array body } \\
\text { coil }\end{array}$ & Two experienced radiologists & $\begin{array}{c}\text { Surgical and } \\
\text { histopathologic } \\
\text { examination }\end{array}$ \\
\hline
\end{tabular}

NCD: not clearly described.

metastases. We found that the pooled sensitivity of US in assessing hepatic metastasis was as low as 0.54 (95\% CI: 0.34-0.73) with an acceptable specificity of 0.98 (95\% CI: 0.90-0.99), and the pooled sensitivity in detecting peritoneal metastasis was 0.09 (95\% CI: 0.03-0.21) with a relatively high specificity of 0.99 (95\% CI: 0.96-1.00). This showed that US was more helpful in patients suspected of liver or peritoneal metastases.

EUS was initially developed primarily to overcome the limitations of abdominal ultrasonography in pancreas and a number of studies provided evidences on the high diagnostic accuracy and important role of EUS in staging of gastric cancer [55]. Compared with abdominal US, EUS has the advantage of placing the transducer close to the lesion without interference of bowel gas, bone or fat. However, EUS has an inherent disadvantage of operator dependency, which was the same as abdominal US. Although it is well suitable for the assessment of T staging, EUS has a limited effect in the overall assessment of more distant spread. Additionally, EUS is an invasive technique requiring sedation which will cause possible sedationrelated complications [11]. Previous studies mainly focused on the usefulness of EUS in the evaluation of local invasion and LN staging $[11,12]$; but studies aiming at assessing the liver and peritoneal metastases were few [30-33]. We did not perform combined analysis using the data of EUS in the evaluation of liver metastases in the case of only two eligible studies. Although the result of our meta-analysis indicated that EUS was the most sensitive imaging modality in detecting peritoneal metastasis, the combined sensitivity was as low as 0.34 (95\% CI: 0.10-0.69). This was similar with another systematic review, which concluded that EUS is not designed to look at distant metastasis [56]. It was reported that laparoscopy facilitated detection of EUS or CT-occult micrometastases on the peritoneal surface or in the liver [57], and identified EUS or CT-occult metastatic disease in $23 \%$ to $37 \%$ of patients $[24,58]$. The result suggested that laparoscopy should be integrated as part of the recommended staging algorithm in the detection of liver and peritoneal metastases in aftertime.

Table 5 Characteristics of the five included 18F-FDG PET studies

\begin{tabular}{|c|c|c|c|c|c|c|c|}
\hline $\begin{array}{c}\text { Study } \\
\text { (year, reference) }\end{array}$ & County & $\begin{array}{l}\text { No. of } \\
\text { patients }\end{array}$ & $\begin{array}{l}\text { Time of } \\
\text { fasting } \\
\text { before } \\
\text { scanning }\end{array}$ & $\begin{array}{c}\text { FDG dose, } \\
\text { time } \\
\text { interval } \\
\text { between } \\
\text { FDG } \\
\text { administration } \\
\text { and scanning }\end{array}$ & $\begin{array}{l}\text { Attenuation } \\
\text { correction, } \\
\text { reconstruction } \\
\text { method }\end{array}$ & Interpreter(s) & Reference standard \\
\hline Lim 2006 [34] & $\begin{array}{l}\text { South } \\
\text { Korea }\end{array}$ & 124 & $4 \mathrm{~h}$ & $\begin{array}{l}370-555 \mathrm{MBq} \\
60 \mathrm{~min}\end{array}$ & $\begin{array}{l}\text { Yes, order } \\
\text { subset } \\
\text { expectation } \\
\text { maximization }\end{array}$ & $\begin{array}{c}\text { Two experienced nuclear } \\
\text { medicine } \\
\text { physicians }\end{array}$ & $\begin{array}{c}\text { Surgical and } \\
\text { histopathologic } \\
\text { standards }\end{array}$ \\
\hline Yoshioka 2003 [35] & $\begin{array}{l}\text { United } \\
\text { States }\end{array}$ & 20 & $4 \mathrm{~h}$ & $\begin{array}{l}\text { Mean } 222 \mathrm{MBq} \\
30 \mathrm{~min}\end{array}$ & Yes, NCD & Three PET specialists & $\begin{array}{l}C T \text {, cytology, } \\
\text { and clinical course }\end{array}$ \\
\hline Yoshioka 2003 [35] & $\begin{array}{l}\text { United } \\
\text { States }\end{array}$ & 22 & $4 \mathrm{~h}$ & $\begin{array}{l}\text { Mean } 222 \mathrm{MBq} \\
\quad 45 \mathrm{~min}\end{array}$ & Yes, NCD & Three PET specialists & $\begin{array}{c}C T \text {, cytology, } \\
\text { and clinical course }\end{array}$ \\
\hline Chen 2005 [36] & $\begin{array}{l}\text { United } \\
\text { States }\end{array}$ & 68 & $4 \mathrm{~h}$ & $\begin{array}{l}370-555 \mathrm{Mbq} \\
60 \mathrm{~min}\end{array}$ & Yes, iterative & $\begin{array}{l}\text { Two experienced } \\
\text { nuclear medicine physicians }\end{array}$ & $\begin{array}{l}\text { Surgical and histological } \\
\text { classification }\end{array}$ \\
\hline Yun 2005 [41] & $\begin{array}{l}\text { United } \\
\text { States }\end{array}$ & 81 & $4 \mathrm{~h}$ & $\begin{array}{l}370 \mathrm{MBq} \\
60 \mathrm{~min}\end{array}$ & Yes, iterative & $\begin{array}{l}\text { Two experienced nuclear } \\
\text { medicine physicians }\end{array}$ & $\begin{array}{l}\text { Histopathologic } \\
\text { examination }\end{array}$ \\
\hline Yeung 1998 [42] & $\begin{array}{l}\text { United } \\
\text { States }\end{array}$ & 23 & $6 \mathrm{~h}$ & $\begin{array}{c}370 \mathrm{MBq} \\
45 \mathrm{~min} \text { to } 1 \mathrm{~h}\end{array}$ & Yes, NCD & $\begin{array}{c}\text { An experienced PET } \\
\text { reader }\end{array}$ & $\begin{array}{l}\text { Histology, surgical findings, } \\
\text { clinical follow-up }\end{array}$ \\
\hline
\end{tabular}


Table 6 Quality assessment of included studies

\begin{tabular}{|c|c|c|c|c|c|c|c|c|c|c|c|c|c|c|c|c|}
\hline \multirow{2}{*}{$\begin{array}{l}\text { Imaging } \\
\text { modality }\end{array}$} & \multirow{2}{*}{$\begin{array}{c}\text { Study } \\
\text { (year, reference) }\end{array}$} & \multicolumn{15}{|c|}{ Criteria of quality assessment } \\
\hline & & 1 & 2 & 3 & 4 & 5 & 6 & 7 & 8 & 9 & 10 & 11 & 12 & 13 & 14 & TS \\
\hline US and CT & Kim 1997 [21] & + & + & + & + & + & + & + & $+/-$ & $+/-$ & $+/-$ & $+/-$ & $+/-$ & $+/-$ & + & 22 \\
\hline US and CT & Stell 1996 [22] & + & + & + & $+/-$ & + & + & + & $+/-$ & $+/-$ & + & $+/-$ & $+/-$ & $+/-$ & + & 22 \\
\hline US and CT & Asencio 1997 [23] & + & + & + & $+/-$ & + & + & + & - & $+/-$ & $+/-$ & $+/-$ & $+/-$ & $+/-$ & - & 18 \\
\hline US & Possik 1986 [24] & + & + & + & $+/-$ & - & + & + & - & $+/-$ & $+/-$ & $+/-$ & $+/-$ & $+/-$ & - & 16 \\
\hline US & Derchi 1983 [25] & + & + & + & $+/-$ & - & - & + & + & $+/-$ & + & $+/-$ & $+/-$ & $+/-$ & + & 19 \\
\hline US & Liao 2004 [26] & + & - & + & $+/-$ & - & - & + & + & $+/-$ & $+/-$ & $+/-$ & $+/-$ & $+/-$ & - & 14 \\
\hline US, EUS and CT & Ozmen 2003 [27] & + & + & + & $+/-$ & - & - & + & - & - & + & + & $+/-$ & $+/-$ & + & 17 \\
\hline $\mathrm{CT}$ & Nozoe 1999 [28] & - & + & + & $+/-$ & - & - & + & $+/-$ & $+/-$ & $+/-$ & $+/-$ & $+/-$ & $+/-$ & + & 15 \\
\hline US and $C T$ & Kayaalp 2002 [29] & + & - & + & $+/-$ & $+/-$ & - & + & $+/-$ & $+/-$ & $+/-$ & $+/-$ & $+/-$ & $+/-$ & + & 16 \\
\hline EUS & Chu 2004 [30] & + & + & + & + & + & + & + & + & $+/-$ & + & + & $+/-$ & $+/-$ & + & 25 \\
\hline EUS & Tio 1990 [31] & - & $+/-$ & + & + & + & - & + & + & $+/-$ & + & $+/-$ & $+/-$ & $+/-$ & + & 19 \\
\hline EUS & Chen 2002 [32] & $+/-$ & $+/-$ & + & + & - & - & + & + & $+/-$ & $+/-$ & $+/-$ & $+/-$ & $+/-$ & + & 17 \\
\hline EUS & Lee 2005 [33] & + & - & $+/-$ & - & - & + & $+/-$ & + & $+/-$ & + & + & $+/-$ & $+/-$ & + & 17 \\
\hline $\mathrm{CT}$ and PET & Lim 2006 [34] & + & - & + & $+/-$ & - & - & + & + & + & $+/-$ & $+/-$ & $+/-$ & $+/-$ & + & 17 \\
\hline PET & Yoshioka 2003 [35] & $+/-$ & - & $+/-$ & $+/-$ & $+/-$ & $+/-$ & + & + & $+/-$ & + & $+/-$ & $+/-$ & $+/-$ & + & 17 \\
\hline CT and PET & Chen 2005 [36] & + & $+/-$ & + & $+/-$ & $+/-$ & $+/-$ & + & + & + & + & $+/-$ & $+/-$ & $+/-$ & + & 21 \\
\hline MRI & Tang 2006 [37] & - & $+/-$ & + & + & $+/-$ & $+/-$ & + & + & $+/-$ & + & $+/-$ & $+/-$ & $+/-$ & + & 19 \\
\hline MRI & Li 2007 [38] & - & $+/-$ & + & + & $+/-$ & $+/-$ & + & + & $+/-$ & + & $+/-$ & $+/-$ & $+/-$ & - & 15 \\
\hline$C T$ & Chamadol 2008 [39] & $+/-$ & $+/-$ & + & - & - & - & + & + & $+/-$ & + & $+/-$ & + & $+/-$ & + & 17 \\
\hline $\mathrm{CT}$ & Yajima 2006 [40] & - & $+/-$ & + & $+/-$ & - & $+/-$ & + & + & $+/-$ & + & $+/-$ & $+/-$ & $+/-$ & + & 17 \\
\hline $\mathrm{CT}$ and PET & Yun 2005 [41] & + & $+/-$ & + & $+/-$ & - & - & $+/-$ & $+/-$ & $+/-$ & + & + & $+/-$ & $+/-$ & + & 17 \\
\hline PET & Yeung 1998 [42] & $+/-$ & $+/-$ & + & $+/-$ & - & - & + & + & $+/-$ & $+/-$ & $+/-$ & $+/-$ & $+/-$ & + & 16 \\
\hline$C T$ & Kim 2005 [43] & $+/-$ & $+/-$ & + & + & - & - & + & + & $+/-$ & + & $+/-$ & $+/-$ & $+/-$ & + & 18 \\
\hline CT & D’Elia 2000 [44] & $+/-$ & $+/-$ & + & $+/-$ & - & - & + & + & $+/-$ & $+/-$ & $+/-$ & $+/-$ & $+/-$ & + & 16 \\
\hline CT & Adachi 1997 [45] & - & $+/-$ & + & $+/-$ & + & $+/-$ & + & $+/-$ & $+/-$ & $+/-$ & $+/-$ & $+/-$ & $+/-$ & + & 17 \\
\hline CT & Shinohara 2005 [46] & - & $+/-$ & + & + & + & + & + & + & $+/-$ & + & $+/-$ & $+/-$ & $+/-$ & + & 21 \\
\hline CT & Davies 1997 [47] & $+/-$ & $+/-$ & + & + & + & + & + & + & + & + & $+/-$ & $+/-$ & $+/-$ & + & 23 \\
\hline CT & Yan 2007 [48] & + & - & + & + & - & - & + & $+/-$ & $+/-$ & + & $+/-$ & $+/-$ & $+/-$ & + & 17 \\
\hline CT & Roic 1994 [49] & $+/-$ & - & + & $+/-$ & - & + & + & $+/-$ & $+/-$ & $+/-$ & $+/-$ & $+/-$ & $+/-$ & - & 14 \\
\hline CT & Gamón 2002 [50] & $+/-$ & - & + & + & $+/-$ & $+/-$ & + & + & $+/-$ & $+/-$ & $+/-$ & $+/-$ & $+/-$ & + & 18 \\
\hline CT & Zhang 2002 [51] & + & - & + & $+/-$ & $+/-$ & $+/-$ & + & + & $+/-$ & $+/-$ & $+/-$ & $+/-$ & $+/-$ & + & 18 \\
\hline CT & Yan 2010 [52] & + & $+/-$ & + & + & + & + & + & + & $+/-$ & + & $+/-$ & $+/-$ & $+/-$ & + & 23 \\
\hline CT & Pan 2010 [53] & + & $+/-$ & + & $+/-$ & + & + & + & $+/-$ & $+/-$ & $+/-$ & $+/-$ & $+/-$ & $+/-$ & + & 20 \\
\hline
\end{tabular}

TS: total score.

Abdominal CT can demonstrate not only the stomach wall and the adjacent tissue, but also the presence of distant metastases by providing rapid and high spatial resolution imaging $[21,59]$. The sensitivity of CT in the detection of liver metastasis ranged from $0.29-1.00$ in included studies [21-24,27-29,44-51,53], the cause of so

Table 7 Spearman correlation coefficient Logit (sensitivity) vs Logit (1- specificity)

\begin{tabular}{cccccccc}
\hline Outcomes & \multicolumn{3}{c}{ Liver metastasis } & \multicolumn{3}{c}{ Peritoneal metastasis } \\
\cline { 2 - 8 } & US & CT & PET & US & EUS & CT & PET \\
\hline ScC & 0.643 & -0.143 & 0.400 & 0.200 & 1.000 & 0.329 & 0.200 \\
p-value & 0.119 & 0.598 & 0.600 & 0.800 & 0.000 & 0.297 & 0.800 \\
\hline
\end{tabular}

Scc: Spearman correlation coefficient.
Table 8 Results of Cochrane-Q test

\begin{tabular}{lcccccccc}
\hline Outcomes & & \multicolumn{3}{c}{ Liver metastasis } & \multicolumn{3}{c}{ Peritoneal metastasis } \\
& & US & CT & PET & US & EUS & CT & PET \\
\hline Sen & Q-value & 23.87 & 40.96 & 7.95 & 7.24 & FC & 82.07 & 6.12 \\
& p-value & 0.00 & 0.00 & 0.09 & 0.12 & FC & 0.00 & 0.19 \\
Spe & Q-value & 153.95 & 77.99 & 19.61 & 5.34 & FC & 57.09 & 34.25 \\
& p-value & 0.00 & 0.00 & 0.00 & 0.25 & FC & 0.00 & 0.00 \\
DOR & Q-value & 88.72 & 40.12 & 30.55 & 18.90 & FC & 23.50 & 44.18 \\
& P-value & 0.00 & 0.00 & 0.00 & 0.00 & FC & 0.05 & 0.00 \\
\hline Sen: sensitivity; Spe: Specificity; DOR: diagnostic odds ratio; FC: failed to \\
calculate.
\end{tabular}


Table 9 Results of diagnostic value of imaging

\begin{tabular}{ccccc}
\hline \multicolumn{2}{c}{ Imaging modality } & Sen $(\mathbf{9 5} \% \mathbf{C l})$ & Spe $(\mathbf{9 5} \% \mathbf{C l})$ & DOR $(\mathbf{9 5} \% \mathbf{C l})$ \\
\hline Liver metastasis & US & 0.54 & 0.98 & 50.25 \\
& & $(0.34-0.73)$ & $(0.90-0.99)$ & $(13.48-187.32)$ \\
& CT & 0.74 & 0.99 & 251.14 \\
& & $(0.59-0.85)$ & $(0.97-1.00)$ & $(83.53-755.07)$ \\
& PET & 0.70 & 0.96 & 56.46 \\
Peritoneal metastasis & & $(0.36-0.90)$ & $(0.81-0.99)$ & $(8.47-376.23)$ \\
& US & 0.09 & 0.99 & 10.63 \\
& & $(0.03-0.21)$ & $(0.96-1.00)$ & $(1.54-73.36)$ \\
& EUS & 0.34 & 0.96 & 13.07 \\
& & $(0.10-0.69)$ & $(0.87-0.99)$ & $(6.42-26.62)$ \\
& CT & 0.33 & 0.99 & 66.18 \\
& & $(0.16-0.56)$ & $(0.98-1.00)$ & $(27.28-160.53)$ \\
& PET & 0.28 & 0.97 & 12.49 \\
& & $(0.17-0.44)$ & $(0.83-1.00)$ & $(2.22-70.10)$ \\
\hline
\end{tabular}

Sen: sensitivity; Spe: Specificity; DOR: diagnostic odds ratio; Cl: confidence interval.

The results were combined using the metandi command (based on bivariate model) in stata software.

wide an interval possibly was the use of different tomography techniques in included studies, for example some researchers used single-detector row $\mathrm{CT}$ but others used multi-detector CT (MDCT), which can overcome the low scanning speed of single-detector row CT by its ability to make thinner sections in a shorter time. In our study we found that the diagnostic accuracy of CT was moderate with a pooled sensitivity of 0.74 (95\% CI: $0.59-0.85$ ) in the detection of liver metastasis. Additionally, the result of meta-analysis indicated that the sensitivity of CT in detecting peritoneal metastasis was very low [0.33 (95\% CI: 0.16-0.56)], which supported the viewpoint that peritoneal metastasis was one of the limitations of CT in predicting the stage of gastric cancer preoperatively [21]. Newer MDCT technology (such as the application of 128- to 256-section MDCT scanners or dual-source technology) was reckoned to improve diagnostic performance with a spatial resolution of $5 \mathrm{~mm}$ or less in diameter [12]. Compared with CT, PET has an advantage of providing functional information. Currently PET is not only being evaluated as a staging tool for gastric cancer, but also useful for monitoring tumor recurrence and response to neoadjuvant therapy $[59,60]$. Although some researchers reported that PET had utilities in detecting liver and peritoneal metastases (the sensitivity could achieve $100 \%$ and $57 \%$ respectively) $[42,61]$, we did not found that ${ }^{18} \mathrm{~F}$-FDG
PET had advantages over CT in the assessment of liver and peritoneal metastases in our meta-analysis. Possible reasons for the reported low to moderate sensitivity of FDG-PET is lack of detailed anatomic information in the area of significant tracer uptake and its limited resolution. It was reported that combining both PET and CT (PET/CT) has demonstrated further improvements in diagnostic accuracy recently [59]. The method unites the high anatomic spatial information from $\mathrm{CT}$ with the functional information offered by PET, and has a benefit of the rapid CT based attenuation correction of PET. This can decrease scanning time and increase the degree of comfort. Pyrimidine analog 3-deoxy-3-18F-fluorothymidine $\left({ }^{18} \mathrm{~F}-\mathrm{FLT}\right)$, a new stable PET tracer was used for improving the diagnostic accuracy lately. It was reported that ${ }^{18} \mathrm{~F}$-FLT had a higher sensitivity than ${ }^{18} \mathrm{~F}$-FDG PET in the detection of locally advanced gastric cancer [62]. However, whether this imaging modality will improve the diagnostic accuracy of liver and peritoneal metastases needs further investigation.

MRI has evolved to be an important imaging method for detection and characterization of most of common diseases of the abdomen including gastric cancer $[63,64]$. Advantages of MRI over CT include the ability of generating significantly greater soft tissue contrast resolution, and the ability of removing the risk of iodinated contrastinduced nephropathy or ionizing radiation [64]. However only two eligible MRI studies $[37,38]$ were identified in our review, and all from China, therefore the data were not combined. The two studies found that MRI had both high sensitivity and specificity in detecting liver metastasis. Some researchers reported that diffusion-weighted (DW) MRI was more sensitive than CT in detecting liver and peritoneal metastases, and functional parameters such as apparent diffusion coefficient (ADC) could monitor the response to neoadjuvant chemotherapy [65]. These results seemed inspiring, whereas the sample size was small and methodological quality was moderate. Therefore more MRI (especially DW-MRI) studies focusing on evaluating the liver and peritoneal metastases are urgently needed in future.

\section{Conclusions}

Although the result of our meta-analysis showed that CT was the most sensitive imaging method with a high rate

Table 10 Results of EUS and MRI in the detection of liver metastases

\begin{tabular}{ccccc}
\hline Imaging modality & Study ID & Sen $(\mathbf{9 5 \%} \mathbf{C l})$ & Spe (95\% CI) & DOR (95\% CI) \\
\hline EUS & Ozmen 2003 [27] & $0.00(0.00-0.46)$ & $0.86(0.71-0.95)$ & $0.43(0.02-8.63)$ \\
& Tio 1990 [31] & $0.67(0.09-0.99)$ & $0.95(0.88-0.99)$ & $38.50(2.85-519.60)$ \\
MRI & Tang 2006 [37] & $1.00(0.40-1.00)$ & $1.00(0.89-1.00)$ & $567.00(9.95-32300.14)$ \\
& Li 2007 [38] & $1.00(0.40-1.00)$ & $1.00(0.87-1.00)$ & $477.00(8.35-27250.55)$ \\
\hline
\end{tabular}

Sen: sensitivity; Spe: Specificity; DOR: diagnostic odds ratio; Cl: confidence interval. 


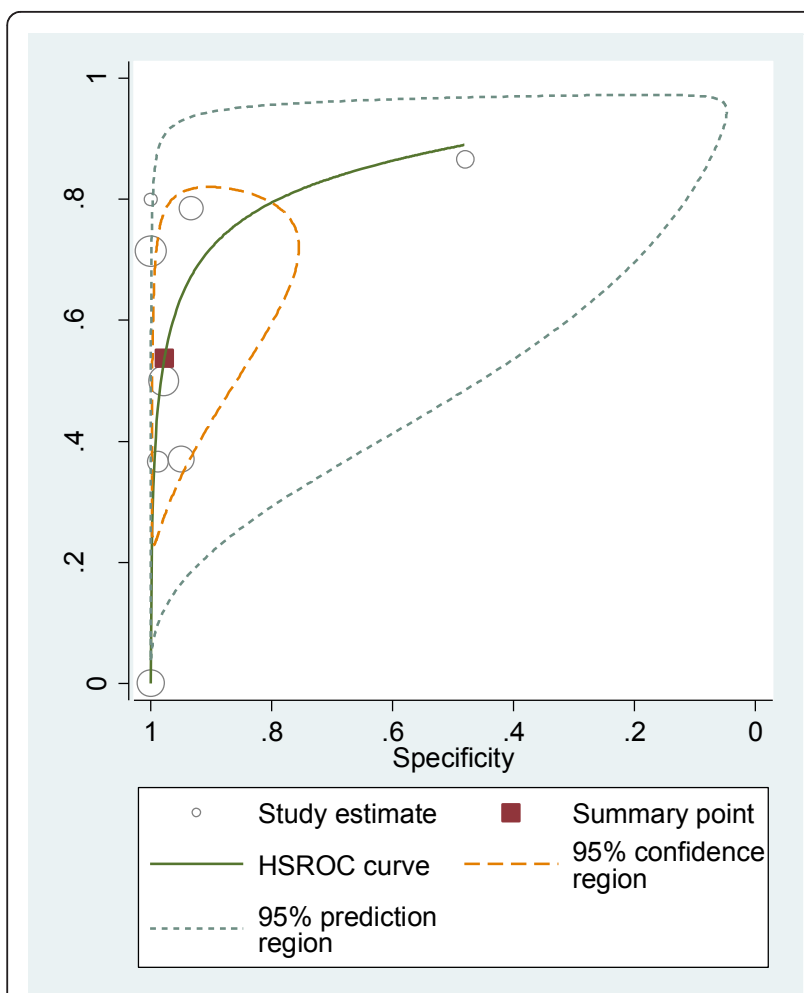

Figure 2 HSROC curve of US for the detection of liver metastases.

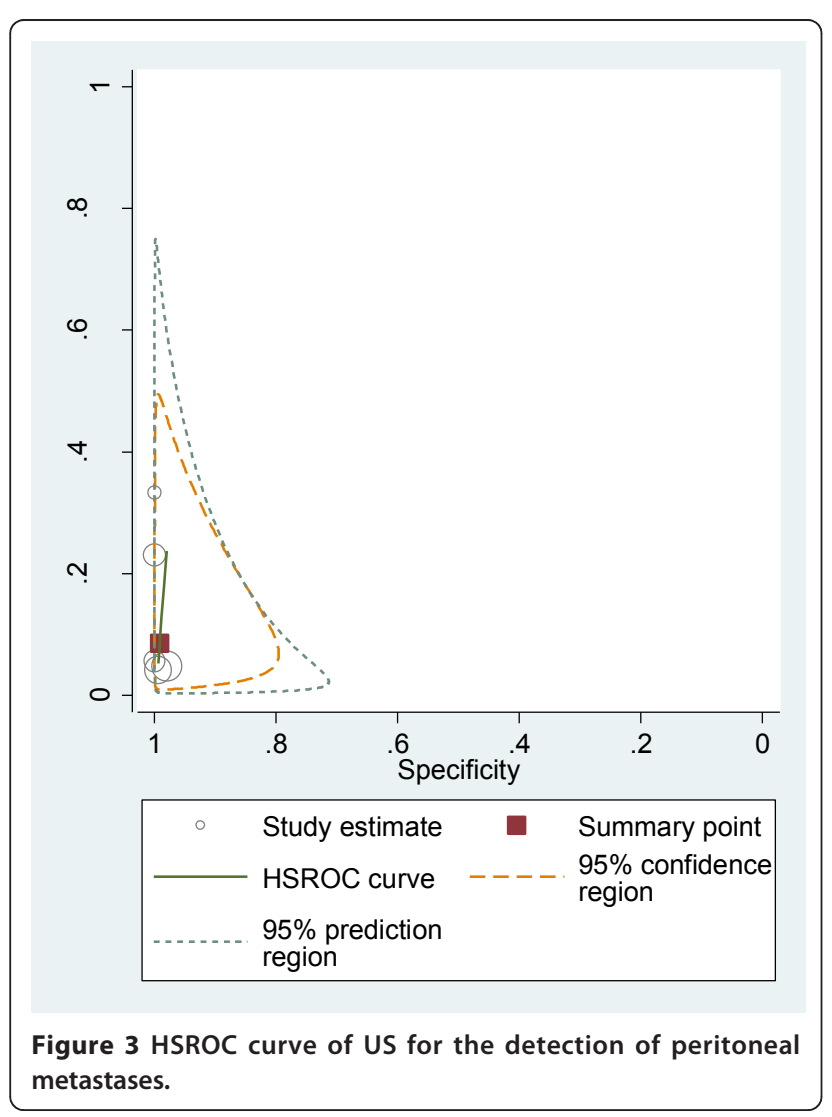

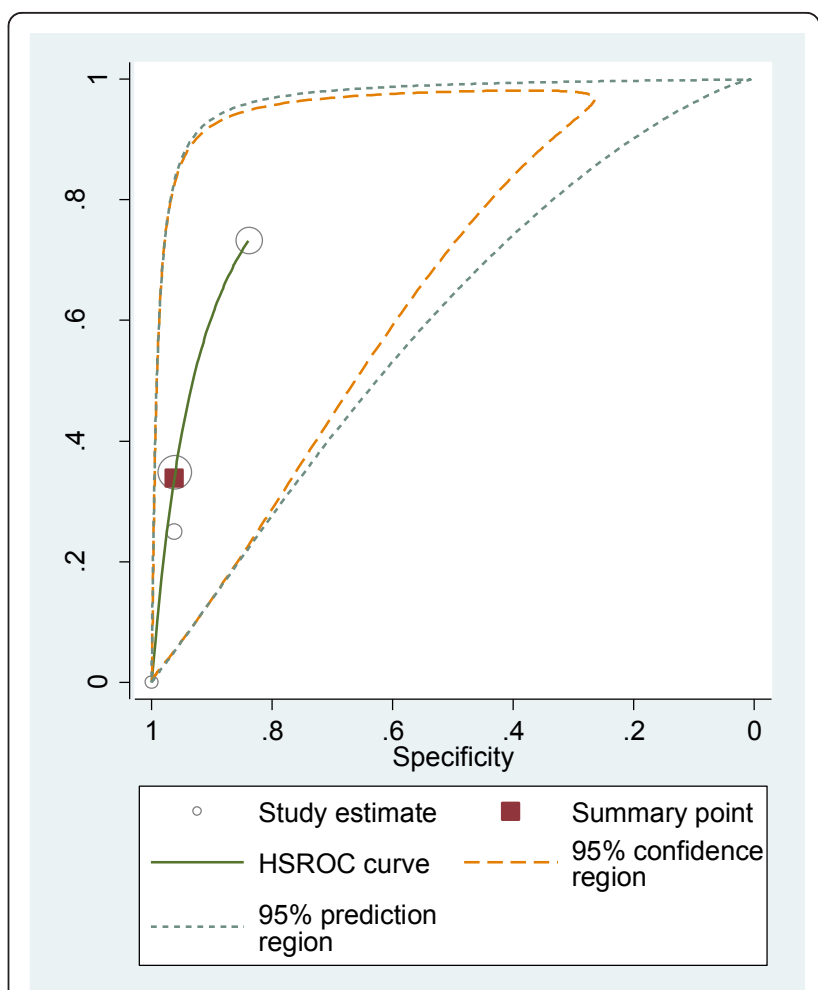

Figure 4 HSROC curve of EUS for the detection of peritoneal metastases.

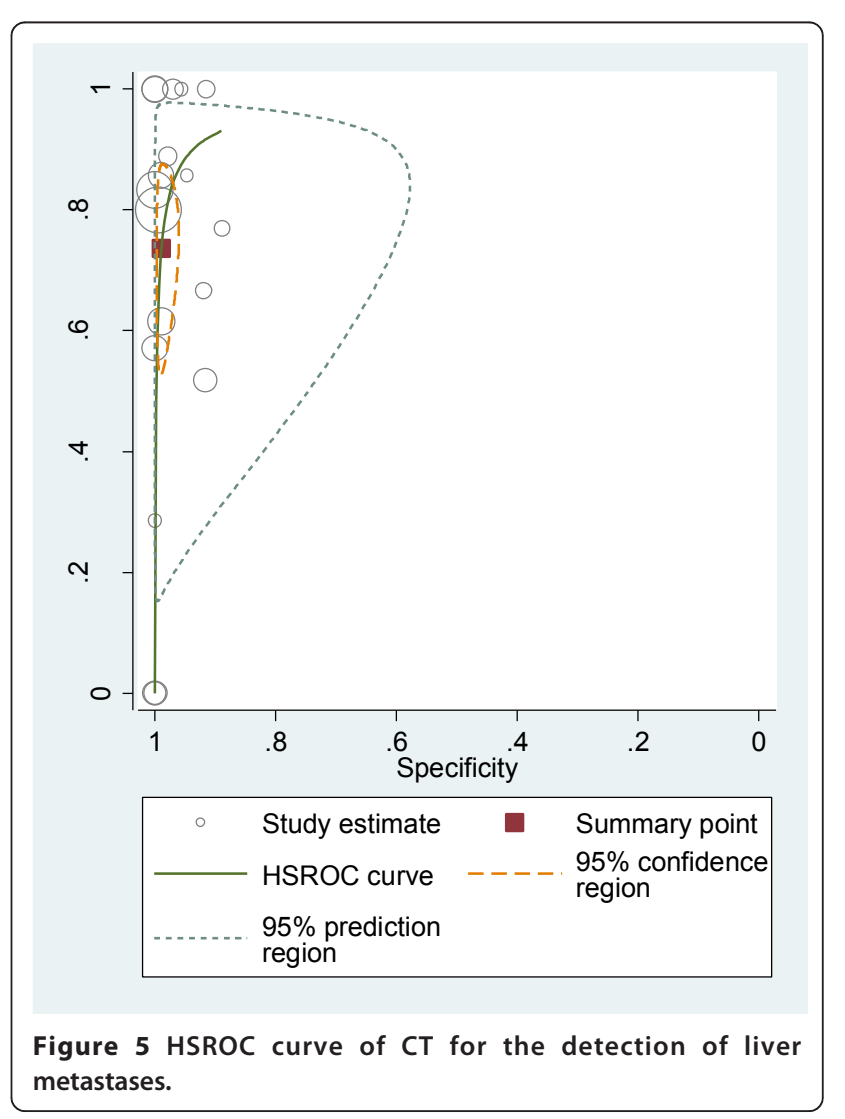



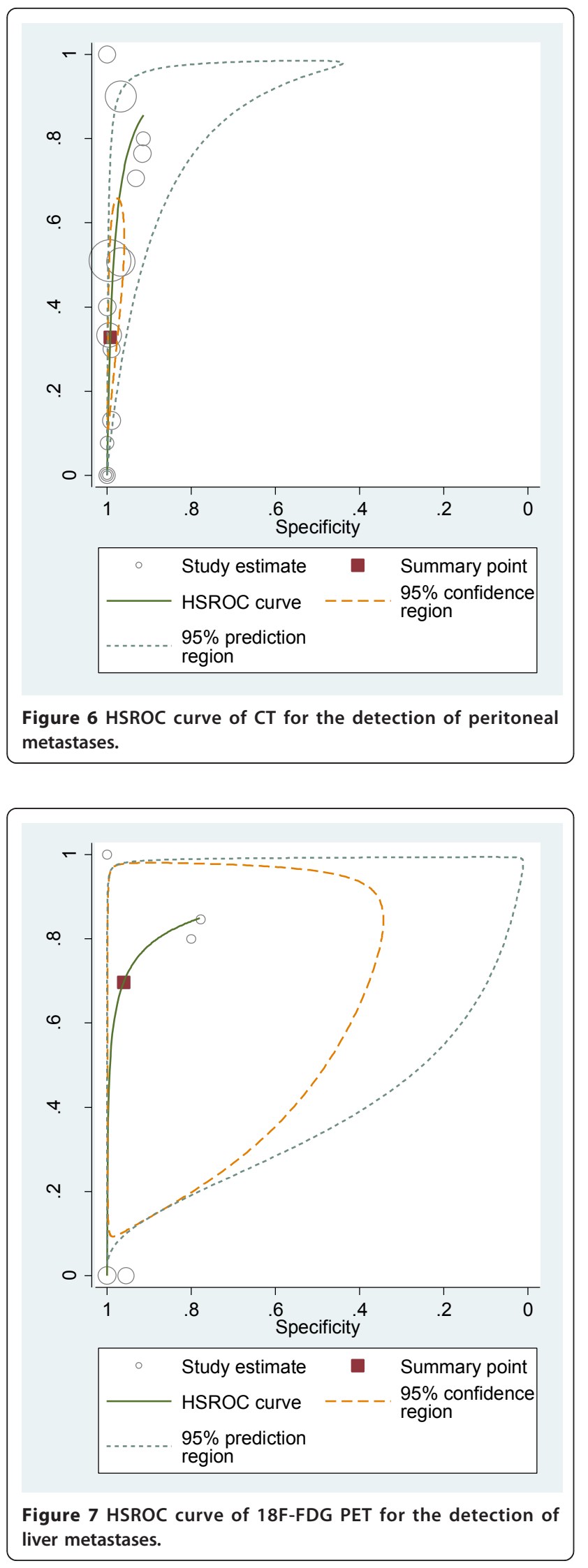

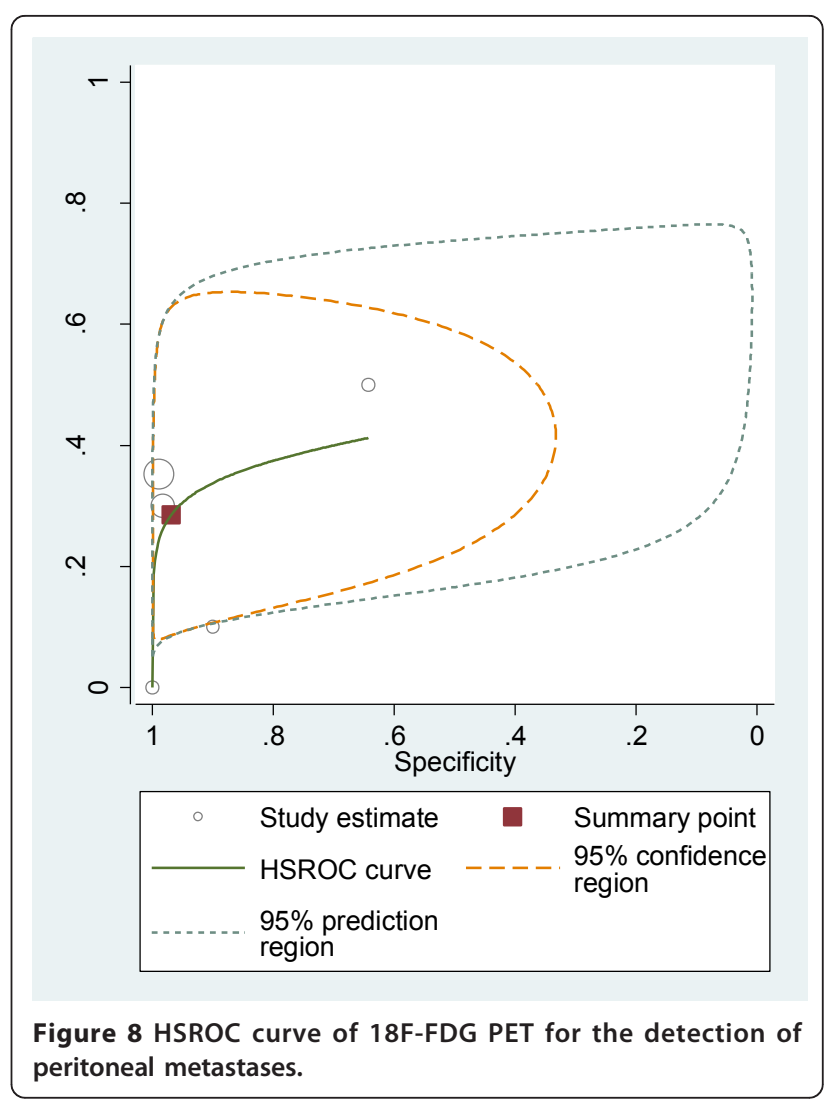

of specificity in detecting hepatic metastasis, and EUS was the most sensitive imaging modality with a relatively low rate of specificity (compared with the three other imaging methods) in detecting peritoneal metastasis, we concluded that US, EUS, CT and ${ }^{18}$ F-FDG PET did not obtain consistently high sensitivity and specificity in detecting liver and peritoneal metastases in patients with gastric cancer. More attention should be paid to laparoscopy, PET/CT, DW-MRI, as well as new PET tracers such as ${ }^{18} \mathrm{~F}$-FLT in the detection of liver and peritoneal metastases of gastric cancer in future.

\section{Appendix}

Midas: is a comprehensive program of statistical and graphical routines for undertaking meta-analysis of diagnostic test performance in Stata. It facilitates exploratory analysis of heterogeneity, publication and other precision-related biases.

Metandi: The metandi command display the results in two alternative parameterizations and produce a customizable plot. It also displays some familiar summary measures (such as sensitivity and specificity). The command requires either Stata 10 or above (which has the new command xtmelogit), or Stata 8.2 or above with gllamm installed. 


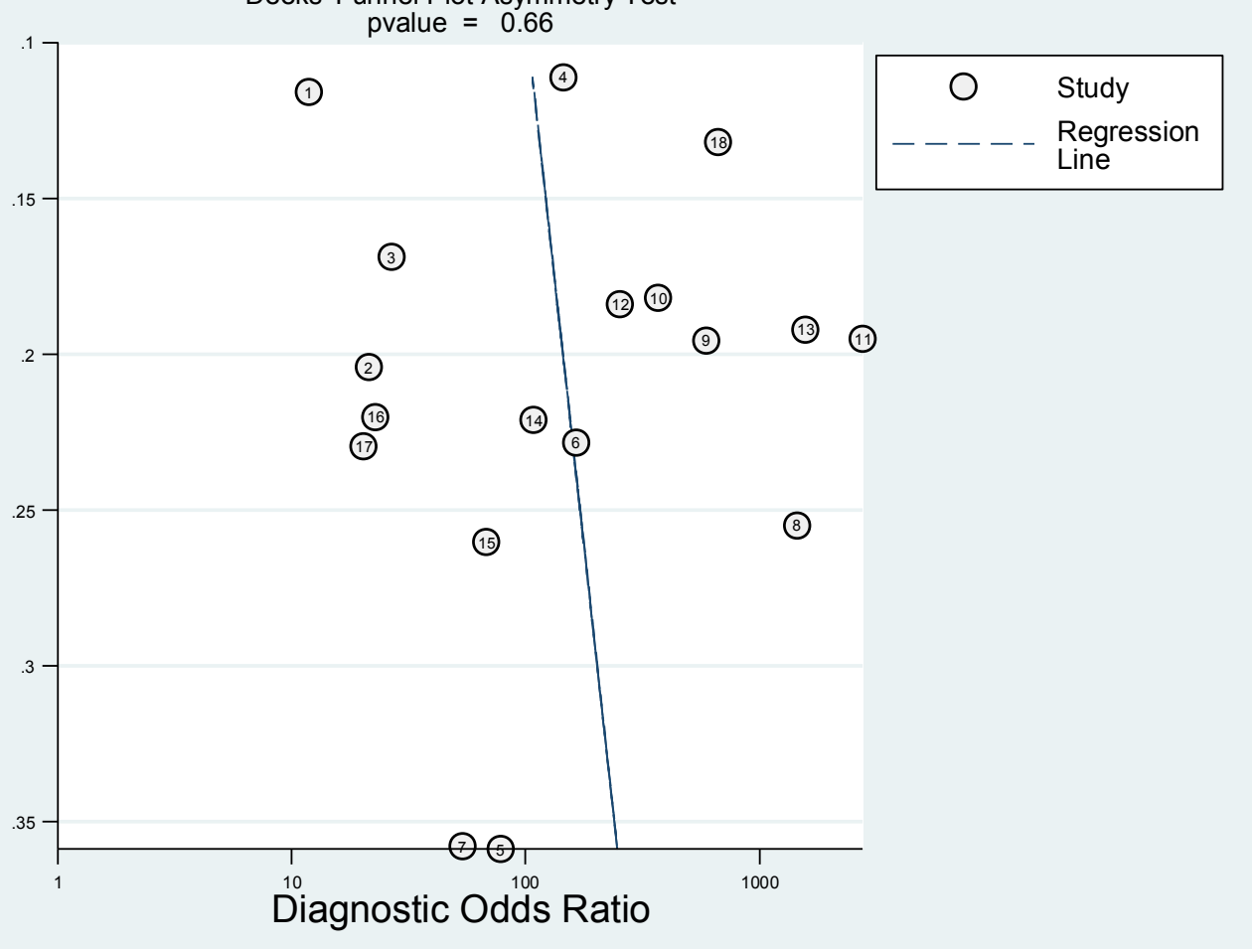

Figure 9 Funnel plot based on the data of CT for the detection of liver metastases.

1. Midas command for testing the heterogeneity of sensitivity and specificity:

midas tp fp fn tn, texts(0.60) bfor(dss) ford fors

2. Midas command for testing the heterogeneity of DOR:

midas tp fp fn tn, texts(0.60) bfor(dlor) ford fors

3. Metandi command for the pooled analysis of sensitivity, specificity and DOR, and for plotting the HSROC curves:

metandi tp fp fn tn, plot

4. Midas command for testing publication bias: midas tp fp fn tn, pubbias

(tp: true positives, fp: false positives, fn: false negatives, tn: true negatives)

\section{Acknowledgements}

We thank Mao Zhifeng (Neurology Department, The First Affiliated Hospital of Guangxi Medical University) for their guidance in statistical analysis. We also thank colleagues from The First Affiliated Hospital of Guangxi Medical University for their warmhearted assistance in developing this manuscript. Supported by The National Natural Science Foundation of China, Grant No. 30560151.

\section{Authors' contributions}

ZW and JQC contributed equally to this article. ZW and JQC designed this study; ZW and Chen JQ performed this research; ZW and JQC analyzed the data; JQC interpreted the results; ZW drafted the manuscript; JQC revised the paper. The two authors both approved the final manuscript.

\section{Competing interests}

The authors declare that they have no competing interests.

Received: 13 September 2010 Accepted: 9 March 2011

Published: 9 March 2011

\section{References}

1. Parkin DM, Bray F, Ferlay J, Pisani P: Global cancer statistics, 2002. CA Cancer J Clin 2005, 55:74-108.

2. Crew KD, Neugut Al: Epidemiology of gastric cancer. World J Gastroenterol 2006, 12:354-362.

3. Roukos DH, Kappas AM: Perspectives in the treatment of gastric cancer. Nat Clin Pract Oncol 2005, 2:98-107.

4. Sakamoto Y, Ohyama S, Yamamoto J, Yamada K, Seki M, Ohta Kl, Kokudo N, Yamaguchi T, Muto T, Makuuchi M: Surgical resection of liver metastases of gastric cancer: An analysis of a 17-year experience with 22 patients. Surgery 2003, 33:507-511.

5. Koga $\mathrm{S}$, Kawaguchi $\mathrm{H}$, Kishimoto $\mathrm{H}$ : Therapeutic significance of noncurative gastrectomy for gastric cancer with liver metastasis. Am J Surg 1980, 140:356-359.

6. Okano K, Maeba T, Ishimura K, Karasawa Y, Goda F, Wakabayashi H, Usuki H, Maeta $\mathrm{H}$ : Hepatic resection for metastatic tumors from gastric cancer. Ann Surg 2002, 235:86-91.

7. Yamada E, Miyaishi S, Nakazato $H$ : The surgical treatment of cancer of the stomach. Int Surg 1980, 65:387-399.

8. Sadeghi B, Arvieux C, Glehen O, Beaujard AC, Rivoire M, Baulieux J, Fontaumard E, Brachet A, Caillot JL, Faure JL, Porcheron J, Peix JL, François $Y$, Vignal J, Gilly FN: Peritoneal carcinomatosis from nongynecologic malignancies: Results of the EVOCAPE 1 multicentric prospective study. Cancer 2000, 88:358-363.

9. Moehler M, Galle PR, Gockel I, Junginger T, Schmidberger H: The multidisciplinary management of gastrointestinal cancer. Multimodal treatment of gastric cancer. Best Pract Res Clin Gastroenterol 2007, 21:965-81. 
10. Power DG, Schattner MA, Gerdes H, Brenner B, Markowitz AJ, Capanu M Coit DG, Brennan M, Kelsen DP, Shah MA: Endoscopic Ultrasound Can Improve the Selection for Laparoscopy in Patients with Localized Gastric Cancer. J Am Coll Surg 2009, 208:173-178.

11. Kwee RM, Kwee TC: Imaging in local staging of gastric cancer: A systematic review. J Clin Oncol 2007, 25:2107-2116.

12. Kwee RM, Kwee TC: Imaging in assessing lymph node status in gastric cancer. Gastric Cancer 2009, 12:6-22.

13. Polkowski M: Endosonographic staging of upper intestinal malignancy. Best Pract Res Clin Gastroenterol 2009, 23:649-661.

14. Whiting P, Rutjes AWS, Reitsma JB, Bossuyt PMM, Kleijnen J: The development of QUADAS: A tool for the quality assessment of studies of diagnostic accuracy included in systematic reviews. BMC Med Res Methodol 2003, 3:1-13.

15. Arends LR, Hamza TH, Van Houwelingen JC, Heijenbrok-Kal MH, Hunink MGM, Stijnen T: Bivariate random effects meta-analysis of ROC curves. Med Decis Making 2008, 28:621-638.

16. Geersing GJ, Janssen KJM, Oudega R, Bax L, Hoes AW, Reitsma JB, Moons KG: Excluding venous thromboembolism using point of care Ddimer tests in outpatients: A diagnostic meta-analysis. BMJ 2009, 339: b2990.

17. Reitsma JB, Glas AS, Rutjes AWS, Scholten RJPM, Bossuyt PM, Zwinderman AH: Bivariate analysis of sensitivity and specificity produces informative summary measures in diagnostic reviews. J Clin Epidemiol 2005, 58:982-90.

18. Deeks JJ, Macaskill P, Irwig L: The performance of tests of publication bias and other sample size effects in systematic reviews of diagnostic test accuracy was assessed. J Clin Epidemiol 2005, 58:882-893.

19. Dwamena BA: Midas: computational and graphical routines for metaanalytical integration of diagnostic accuracy studies in Stata. Division of NuclearMedicine, Department of Radiology, University of Michigan Medical School, Ann Arbor, Michigan; 2007.

20. Harbord RM: Metandi: Stata module for meta-analysis of diagnostic accuracy. Statistical Software Components. Boston College, Departement of Economics; 2008.

21. Kim JJ, Jung HC, Song IS, Choi KW, Kim CY, Han JK, Choi Bl, Park JG, Lee KU, Choe KJ, Kim WH: Preoperative evaluation of the curative resectability of gastric cancer by abdominal computed tomography and ultrasonography: a prospective comparison study. Korean J Intern Med 1997, 12:1-6

22. Stell DA, Carter CR, Stewart I, Anderson JR: Prospective comparison of laparoscopy, ultrasonography and computed tomography in the staging of gastric cancer. Br J Surg 1996, 83:1260-1262.

23. Asencio F, Aguiló J, Salvador JL, Villar A, De la Morena E, Ahamad M, Escrig J, Puche J, Viciano V, Sanmiguel G, Ruiz J: Video-laparoscopic staging of gastric cancer. A prospective multicenter comparison with noninvasive techniques. Surg Endosc 1997, 11:1153-1158.

24. Possik RA, Franco EL, Pires DR: Sensitivity, specificity, and predictive value of laparoscopy for the staging of gastric cancer and for detection of liver metastases. Cancer 1986, 58:1-6.

25. Derchi LE, Biggi E, Rollandi GA: Sonographic staging of gastric cancer. AJR Am J Roentgenol 1983, 140:273-276.

26. Liao SR, Dai Y, Huo L, Yan K, Zhang L, Zhang H, Gao W, Chen MH: Transabdominal ultrasonography in preoperative staging of gastric cancer. World J Gastroenterol 2004, 10:3399-3404.

27. Ozmen MM, Zulfikaroglu B, Ozalp N, Ziraman I, Hengirmen S, Sahin B: Staging laparoscopy for gastric cancer. Surg Laparosc Endosc Percutan Tech 2003, 13:241-244

28. Nozoe T, Matsumata T, Sugimachi K: Usefulness of preoperative transvaginal ultrasonography for women with advanced gastric carcinoma. Am J Gastroenterol 1999, 94:2509-2512.

29. Kayaalp C, Arda K, Orug T, Ozcay N: Value of computed tomography in addition to ultrasound for preoperative staging of gastric cancer. Eur $J$ Surg Oncol 2002, 28:540-543.

30. Chu KM, Kwok KF, Law S, Wong KH: A prospective evaluation of catheter probe EUS for the detection of ascites in patients with gastric carcinoma. Gastrointest Endosc 2004, 59:471-474.

31. Tio TL, Coene PPLO, Luiken GJHM, Tytgat GNJ: Endosonography in the clinical staging of esophagogastric carcinoma. Gastrointest Endosc 1990, 36:S2-S10.
32. Chen $\mathrm{CH}$, Yang $\mathrm{CC}$, Yeh $\mathrm{YH}$ : Preoperative staging of gastric cancer by endoscopic ultrasound: The prognostic usefulness of ascites detected by endoscopic ultrasound. J Clin Gastroenterol 2002, 35:321-327.

33. Lee YT, Ng EKW, Hung LCT, Chung SCS, Ching JYL, Chan WY, Chu WC, Sung JJ: Accuracy of endoscopic ultrasonography in diagnosing ascites and predicting peritoneal metastases in gastric cancer patients. Gut 2005, 54:1541-1545.

34. Lim JS, Kim MJ, Yun MJ, Oh YT, Kim JH, Hwang HS, Park MS, Cha SW, Lee JD, Noh SH, Yoo HS, Kim KW: Comparison of CT and 18F-FDG pet for detecting peritoneal metastasis on the preoperative evaluation for gastric carcinoma. Korean J Radiol 2006, 7:249-256.

35. Yoshioka T, Yamaguchi K, Kubota K, Saginoya T, Yamazaki T, Ido T, Yamaura G, Takahashi H, Fukuda H, Kanamaru R: Evaluation of 18F-FDG PET in patients with a, metastatic, or recurrent gastric cancer. J NuCl Med 2003, 44:690-699.

36. Chen J, Cheong JH, Mi JY, Kim J, Joon SL, Woo JH, Sung HN: Improvement in preoperative staging of gastric adenocarcinoma with positron emission tomography. Cancer 2005, 103:2383-2390.

37. Tang QF, Shen JK, Feng YZ, Wang GZ, Zhang CY, Qian MH: Evaluation of dynamic $0.5 \mathrm{~T}$ MRI in preoperative TNM-staging of advanced gastric carcinoma. Chinese Journal of Medical Imaging Technology 2006, 22:88-91.

38. Li SF, Zhao RF, Li HB, Li JD, Jin JL: Dynamic contrast enhanced MR study on preoperative TNM staging of advanced gastric carcinoma. Chinese Journal of Medical Imaging Technology 2007, 23:1187-1190.

39. Chamadol N, Wongwiwatchai J, Bhudhisawasd V, Pairojkul C: Accuracy of spiral CT in preoperative staging of gastric carcinoma: Correlation with surgical and pathological findings. J Med Assoc Thai 2008, 91:356-363.

40. Yajima K, Kanda T, Ohashi M, Wakai T, Nakagawa S, Sasamoto R, Hatakeyama K: Clinical and diagnostic significance of preoperative computed tomography findings of ascites in patients with advanced gastric cancer. Am J Surg 2006, 192:185-190.

41. Yun M, Lim JS, Noh SH, Hyung WJ, Cheong JH, Bong JK, Cho A, Lee JD: Lymph node staging of gastric cancer using18F-FDG PET: A comparison study with CT. J Nucl Med 2005, 46:1582-1588.

42. Yeung HW, Macapinlac H, Karpeh M, Finn RD, Larson SM: Accuracy of FDGPET in Gastric Cancer. Preliminary Experience. Clin Positron Imaging 1998, 1:213-221.

43. Kim HJ, Kim AY, Oh ST, Kim JS, Kim KW, Kim PN, Lee MG, Ha HK: Gastric cancer staging at multi-detector row CT gastrography: Comparison of transverse and volumetric CT scanning. Radiology 2005, 236:879-885.

44. D'Elia F, Zingarelli A, Palli D, Grani M: Hydro-dynamic CT preoperative staging of gastric cancer: Correlation with pathological findings. A prospective study of 107 cases. Eur Radiol 2000, 10:1877-1885.

45. Adachi Y, Sakino I, Matsumata T, Iso Y, Yoh R, Kitano S, Okudaira Y: Preoperative assessment of advanced gastric carcinoma using computed tomography. Am J Gastroenterol 1997, 92:872-875.

46. Shinohara T, Ohyama S, Yamaguchi T, Muto T, Kohno A, Ogura T, Kato Y, Urashima M: Preoperative TNM staging of advanced gastric cancer with multi-detector row computed tomography. Japan Medical Association Journal 2005, 48:175-182

47. Davies J, Chalmers AG, Sue-Ling HM, May J, Miller GV, Martin IG, Johnston D: Spiral computed tomography and operative staging of gastric carcinoma: A comparison with histopathological staging. Gut 1997, 41:314-319.

48. Yan C, Zhu ZG, Yan M, Chen KM, Chen J, Liu BY, Yin HR, Lin YZ: Clinical significance of multi-slice spiral CT and serum tumor markers in the preoperative assessment of gastric carcinoma. World Chinese Journal of Digestology 2007, 15:3194-3203.

49. Roic G, Marotti M, Zovak M, Klaric R, Krolo I, Roic D: Accuracy of preoperative $\mathrm{CT}$ scanning in staging of gastric carcinoma. Radiother Oncol 1994, 28:114-118.

50. Gamón Giner R, Escrig Sos J, Salvador Sanchís JL, Ruiz del Castillo J, García Vila JH, Marcote Valdivieso E: Helical CT evaluation in the preoperative staging of gastric adenocarcinoma. Rev Esp Enferm Dig 2002, 94:597-600.

51. Zhang HX, Wang HY, Shen BZ, Qu LY, Yu SJ: The clinical value of CT in the diagnosis of gastric cancer. Journal of Practical Oncology 2002, 16:262-264.

52. Yan C, Zhu ZG, Yan M, Chen KM, Chen J, Xiang M, Chen MM, Liu BY, Yin HR, Lin YZ: Value of multidetector-row CT in the preoperative prediction of peritoneal metastasis from gastric cancer: a single-center 
and large-scale study. Chinese journal of gastrointestinal surgery 2010, 13:106-110.

53. Pan Z, Zhang H, Yan C, Du L, Ding B, Song Q, Ling H, Huang B, Chen K: Determining gastric cancer resectability by dynamic MDCT. European Radiology 2010, 20:613-620.

54. Glas AS, Lijmer JG, Prins MH, Bonsel GJ, Bossuyt PMM: The diagnostic odds ratio: a single indicator of test performance. J Clin Epidemiol 2003, 56:1129-35.

55. Tamerisa R, Irisawa A, Bhutani MS: Endoscopic ultrasound in the diagnosis, staging, and management of gastrointestinal and adjacent malignancies. Med Clin North Am 2005, 89:139-158.

56. Puli SR, Batapati Krishna Reddy J, Bechtold ML, Antillon MR, Ibdah JA: How good is endoscopic ultrasound for TNM staging of gastric cancers? A meta-analysis and systematic review. World J Gastroenterol 2008, 14:4011-4019.

57. Abdalla EK, Pisters PWT: Staging and preoperative evaluation of upper gastrointestinal malignancies. Semin Oncol 2004, 31:513-529.

58. Feussner H, Omote K, Fink U, Walker SJ, Siewert JR: Pretherapeutic laparoscopic staging in advanced gastric carcinoma. Endoscopy 1999, 31:342-347.

59. Chin BB: Clinical Utility of Combined 18F-Fluoro-2-deoxyglucose Positron Emission Tomography - Computed Tomography in the Evaluation of Gastrointestinal Malignancies. Curr Med Imaging Rev 2008, 4:255-269.

60. Dassen AE, Lips DJ, Hoekstra CJ, Pruijt JFM, Bosscha K: FDG-PET has no definite role in preoperative imaging in gastric cancer. Eur J Surg Oncol 2009, 35:449-455.

61. Turlakow A, Yeung HW, Salmon AS, Macapinlac HA, Larson SM: Peritoneal carcinomatosis: Role of 18F-FDG PET. J Nucl Med 2003, 44:1407-1412

62. Herrmann K, Ott K, Buck AK, Lordick F, Wilhelm D, Souvatzoglou M, Becker K, Schuster T, Wester HJ, Siewert JR, Schwaiger M, Krause BJ Imaging gastric cancer with PET and the radiotracers $18 \mathrm{~F}-\mathrm{FLT}$ and $18 \mathrm{~F}-$ FDG: A comparative analysis. J Nucl Med 2007, 48:1945-1950

63. Chung JJ, Semelka RC, Martin DR, Marcos HB: Colon diseases: MR evaluation using combined T2-weighted single-shot echo train spinecho and gadolinium-enhanced spoiled gradient-echo sequences. Nucl Med Commun 2000, 12:297-305.

64. Martin DR, Danrad R, Herrmann K, Semelka RC, Hussain SM: Magnetic resonance imaging of the gastrointestinal tract. Top Magn Reson Imaging 2005, 16:77-98.

65. Roth $Y$, Tichler T, Kostenich G, Ruiz-Cabello J, Maier SE, Cohen JS, Orenstein A, Mardor Y: High-b-value diffusion-weighted MR imaging for pretreatment prediction and early monitoring of tumor response to therapy in mice. Radiology 2004, 232:685-692.

Pre-publication history

The pre-publication history for this paper can be accessed here: http://www.biomedcentral.com/1471-230X/11/19/prepub

doi:10.1186/1471-230X-11-19

Cite this article as: Wang and Chen: Imaging in assessing hepatic and peritoneal metastases of gastric cancer: a systematic review. BMC Gastroenterology 2011 11:19

\section{Submit your next manuscript to BioMed Central and take full advantage of:}

- Convenient online submission

- Thorough peer review

- No space constraints or color figure charges

- Immediate publication on acceptance

- Inclusion in PubMed, CAS, Scopus and Google Scholar

- Research which is freely available for redistribution

Submit your manuscript at www.biomedcentral.com/submit 